В.О. Табуненко ${ }^{1}$, О.П. Марценяк ${ }^{2}$, В.І. Кужелович ${ }^{2}$

${ }^{1}$ Харківський національний університет Повітряних Сил ім. I. Кожедуба, Харків

${ }^{2}$ Начіональна академія Національної гвардї України, Харків

\title{
УДОСКОНАЛЕННЯ МЕТОДУ ОЦІНКИ ПОКАЗНИКІВ ВІДНОВЛЮВАНОСТІ ОЗБРОЄННЯ ТА ВІЙСЬКОВОЇ ТЕХНІКИ В УМОВАХ БОЙОВИХ ДІЙ
}

\begin{abstract}
В теперішній час забезпечення боєздатності озброєння і військової техніки на необхідному рівні залежить від організаиії заходів технічного забезпечення, його відновлення, яке здійснюється з метою приведення пошкоджених виробів військової техніки в готовність до бойового застосування. Але, поняття відновлюваності озброєння та військової техніки не визначене державними стандартами, унаслідок чого виникають усілякі тлумачення цісї властивості. В роботі проведений аналіз найбільш вживаних визначень відновлюваності та отримані залежності для оичінки рівня відновлюваності виробів військової техніки при виконанні завдань за призначенням.
\end{abstract}

Ключові слова: система відновлення, озброєння і військова техніка, система технічного забезпечення, комплексні властивості, коефіцієнт відновлюваності.

\section{Вступ}

Постановка проблеми. При веденні сучасних бойових дій, з урахуванням наявності у противника високоточних засобів ураження, забезпечення боєздатності озброєння і військової техніки (ОВТ) на необхідному рівні залежить від організації заходів технічного забезпечення, а конкретніше, відновлення ОВТ [1-2].

Відновлення ОВТ здійснюється з метою приведення пошкодженого ОВТ в готовність до бойового застосування [3]. Відновлення включає: технічну розвідку, евакуацію, ремонт (відновлення працездатності) зразків військової техніки та доведення їх до боєздатного стану [4].

Завданням підрозділів відновлення ОВТ є постійне підтримання боєздатності військових частин 3 точки зору наявності у строю боєздатної військової техніки і озброєння шляхом розвідки пошкоджених зразків, підготовки їх до евакуації, проведення ремонту та повернення їх у військові частини.

Досвід проведення Операції Об'єднаних сил (ООC) на території Донецької та Луганської областей свідчить, що успіх у виконанні завдань військовими частинами (угрупуванням військ) під час ведення бойових дій (операції) залежить від функціонування системи відновлення ОВТ, яка $є$ однією із функцій системи технічного забезпечення Збройних Сил України [5]. Тому, питання, які пов'язані з удосконаленням методичних підходів щодо функціонування системи відновлення ОВТ та методів оцінки показників відновлюваності $є$ досить актуальними та потребують дослідження.
Аналіз останніх досліджень і публікацій. Науковою основою досліджень 3 оцінки рівня відновлюваності ОВТ є теорія ефективності застосування озброєння та військової техніки, експлуатація озброєння та військової техніки, основи теорії надійності озброєння та військової техніки, теорія ймовірностей та математична статистика. Основні залежності, які використовуються при визначенні рівня відновлюваності військово-технічних систем, наведені в роботах [6-8].

Але, до теперішнього часу, поняття відновлюваності озброєння та військової техніки не визначене державними стандартами, унаслідок чого виникають усілякі тлумачення цієї властивості.

Так в роботі [4] дано наступне визначення: відновлення військової техніки - це комплекс організаційно-технічних заходів (робіт), спрямованих на приведення зразків військової техніки у готовність до використання за призначенням i повернення їx до строю.

У Постанові Кабінету Міністрів України від 26 липня 2018 р. № 591 “Про внесення змін до Порядку відновлення, ремонту, модернізації, збільшення установленого ресурсу та продовження строку служби (зберігання) озброєння, військової і спеціальної техніки, за якими не здійснюється авторський нагляд, та визнання такими, що втратили чинність, деяких постанов Кабінету Міністрів України” дано наступне визначення: відновлення військової техніки - це комплекс організаційно-технічних заходів, спрямованих на приведення зразків військової техніки, що вийшли з ладу в ході експлуатації, у готовність до використання за призначенням, і включає технічну розвідку, евакуацію, ремонт (відновлення 
працездатності) зразків військової техніки та доведення їх до боєздатного стану.

В роботі [9] - відновлюваність це ступінь пристосованості ОВТ до відновлення боєздатності (працездатності) після бойових пошкоджень і відмов.

В стандарті [10] - відновлюваність - властивість ОВТ, яка полягає в пристосованості до відновлення працездатного стану після бойових пошкоджень шляхом проведення ремонтів в заданих умовах бойового застосування і обмеженнях.

В роботі [11] під відновлюваністю об'єкту розуміється пристосованість його до відновлення працездатності і здібність обслуговуючої системи до оперативного усунення відмов.

Поняття ремонтопридатність і відновлюваність викладені в стандарті CША MIL-STD-778 і визначаються терміном ремонтопридатність, як характеристика конструкції виробу, яка виражається вірогідністю того, що виріб буде відновлений до певного стану протягом заданого часу, якщо ремонт виконується методами і засобами, що рекомендовані [12].

В роботі [6] відновлюваність - комплекс управляючих дій за визначенням місцезнаходження пошкоджених об'єктів, їх діагностування, при необхідності евакуацію в заданий район, відновлення їх працездатності та повернення до місця призначення.

Таким чином, відновлюваність є одним 3 показників техніко-експлуатаційних можливостей бойових властивостей ОВТ, тобто дозволяє забезпечувати пристосованість ОВТ до усунення бойових пошкоджень і приведення в боєздатний стан в короткі терміни.

Проведений аналіз найбільш вживаних із визначень відновлюваності дозволяє виділити два спільних моменти. Перший полягає в тому, що “відновлюваність ОВТ - пристосовуваність ОВТ до відновлення боєздатності”. Другий полягає в тому, що відновлюваність визначається здібністю системи технічного забезпечення до усунення бойових пошкоджень.

Крім того, з наведених визначень витікає, що відновлюваність $є$ комплексною властивістю.

При цьому, у відомих роботах не наведені комплексні показники відновлюваності ОВТ та данні $з$ узагальнення оцінки існуючого рівня відновлюваності і визначення іiі потрібного рівня перспективних виробів військової техніки.

Мета статті - отримати залежності для оцінки рівня відновлюваності виробів військової техніки при виконанні завдань за призначенням.

\section{Виклад основного матеріалу}

Аналіз властивості “відновлюваність ОВТ” дає можливість запропонувати наступне визначення цього поняття.
Відновлюваність військової техніки - властивість ОВТ пристосовуватися до відновлення боєздатності з урахуванням здібності системи технічного забезпечення до усунення бойових пошкоджень.

Головними особливостями відновлюваності можна вважати:

а) здатність пристосовуватися до відновлення боєздатності. Цей фактор вказує на те, що відновлюваність є властивістю зразків ОВТ, конструкція яких зорієнтована на максимально можливе пристосовування до відновлення в бойових умовах;

б) здатність враховувати здібність системи технічного забезпечення до усунення бойових пошкоджень.

Основні властивості відновлюваності:

а) вона залежить від великої кількості факторів, багато з яких є випадковими;

б) іiі важко визначити єдиним кількісним показником;

в) відновлюваність є складною комплексною властивістю, до теперішнього часу не повністю сформованою.

До комплексної властивості відновлюваність ОВТ входять наступні складові: технічна розвідка, евакуація пошкоджених зразків, ремонт (відновлення працездатності) пошкоджених зразків військової техніки

Ремонт озброєння і техніки включає комплекс робіт по відновленню його справності, працездатності і відновленню ресурсу зразка озброєння і техніки або його складових частин.

В ході бойових дій ремонт озброєння і техніки допускається проводити в скороченому обсязі 3 виконанням тільки тих робіт, які дозволяють використовувати зразки за прямим призначенням, але 3 обов'язковим завершенням інших робіт після виконання бойового завдання [4].

Кількісно відновлюваність ОВТ може оцінюватися: ймовірністю відновлення ОВТ за заданий час; інтенсивністю відновлення; середнім часом відновлення; середньою працемісткістю ремонту та іншими.

3 урахуванням розглянутих складових відновлюваності та того факту, що умови бойового застосування ОВТ носять випадковий характер і мають імовірнісні характеристики, пропонується оцінювати відновлюваність ОВТ комплексним показником узагальненим коефіцієнтом відновлюваності ОВТ $K_{B}$, який визначається наступним чином:

$$
K_{B}=P_{B 3 T P} \cdot P_{E 6 .} \cdot P_{B},
$$

де $P_{B 3 T P}$ - ймовірність виконання завдань 3 проведення технічної розвідки;

$P_{E \text { в. }}$ - ймовірність проведення евакуації пошкодженого зразку; 
$P_{B}$ - ймовірність виконання ремонту (відновлення боєздатного стану) ОВТ після виникнення бойового пошкодження.

Розглянемо основні складові виразу (1). Ймовірність виконання завдання 3 технічної розвідки $P_{B 3 T P}$ - ймовірність того, що завдання з проведення технічної розвідки буде виконано:

$$
P_{\text {ВзТР }}=K_{O Г} \cdot P_{M \Pi} \cdot P_{\Pi П \Pi} \cdot P_{\text {ВПз }},
$$

де $K_{O Г}$ - коефіцієнт оперативної готовності машини до проведення технічної розвідки;

$P_{M \Pi}$ - ймовірність подолання маршруту пошуку машиною технічної розвідки;

$P_{\text {ППП }}$ - ймовірність подолання машиною протидії противника;

$P_{B П 3}$ - ймовірність виявлення пошкоджених зразків ОВТ.

Коефіцієнт оперативної готовності - ймовірність того, що машини для проведення технічної розвідки виявляться в працездатному стані у будьякий момент часу, i, починаючи 3 цього моменту, будуть працювати безвідмовно протягом заданого періоду [7; 13]:

$$
K_{O \Gamma}(t)=\frac{T_{0}}{T_{0}+T_{B}} e^{-\frac{t}{T_{0}}},
$$

де $T_{0}$-середній час безвідмовної роботи машини технічної розвідки, год.;

$T_{B}$ - випадковий час відновлення машини технічної розвідки, год.;

$t$ - час використання машин технічної розвідки, год.

Ймовірність подолання маршруту руху машиною технічної розвідки $\mathrm{P}_{M \Pi}$ - ймовірність того, що машина технічної розвідки здійснить переміщення в конкретних умовах і режимах руху.

Значення ймовірності $\mathrm{P}_{\text {мп }}$ може бути визначено наступним чином:

$$
P_{M \Pi}=\frac{N_{i}}{N_{\max }} ;
$$

де $N_{i}$-поточний показник прохідності машини технічної розвідки;

$N_{\max }$ - максимально можливий показник прохідності машини технічної розвідки.

Ймовірність уникнення втрат машин під час розвідки $P_{\text {ППП }}$, в умовах протидії противника залежить від:

- готовності особового складу до відбиття нападу, рівня підготовки водіїв; скритності пересування;

- часу знаходження під вогнем противника та інших факторів.

Наприклад, ймовірність ураження $P_{y p}$ машини технічної розвідки з урахуванням часу ії знаходження під вогнем противника і моменту іiі виявлення визначається за допомогою виразу [14]:

$$
P_{y p}=1-\frac{1}{p \cdot \lambda \cdot t}\left[1-e^{-p \cdot \lambda \cdot t}\right],
$$

де $\lambda$ - число пострілів по машині за одиницю часу, $1 /$ год.;

$t=t^{*}-T$, год;

$t^{*}-$ час знаходження машини технічної розвідки в зоні обстрілу, год;

$T$ - момент часу виявлення машини технічної розвідки, год;

$p$ - імовірність попадання в ціль.

Ймовірність подолання (уникнення втрат машин технічної розвідки) протидії противника визначається виразом:

$$
P_{\text {ППП }}=1-P_{y p}
$$

Ймовірність виявлення пошкоджених засобів OBT - $P_{\text {ВПз }}$ може бути визначена наступним чином:

$$
P_{B \Pi 3}=\frac{R_{i}}{R_{\max }},
$$

де $R_{i}$ - поточна кількість розвіданих пошкоджених машин, од.;

$R_{\max }$ - максимально можлива кількість розвіданих пошкоджених машин, од.

Поточну кількість пошкоджених зразків ОВТ $N_{T x P}^{p}$, які може розвідати машина технічної розвідки, розраховують за формулою [7]:

$$
N_{T x P}^{p}=\frac{t_{T x P}}{T_{T x P}^{p}},
$$

де $N_{T x P}^{p}$-кількість пошкоджених зразків ОВТ, що можуть бути розвідані рухомим органом технічної розвідки, од.;

$t_{T x P}$ - час ведення технічної розвідки без урахування часу на переміщення, год;

$T_{T x P}^{p}$ - час, потрібний рухомому органу технічної розвідки для виконання заходів щодо технічної розвідки по одному пошкодженому зразку ОВТ, год.

Ймовірність проведення евакуації пошкодженого зразку $-P_{E в \text {. }}$ :

$$
P_{E \text { в. }}=\frac{K_{E в}}{K_{\text {Роз. }}}
$$

де $K_{E в}-$ кількість евакуйованих зразків ОВТ, од.;

$K_{\text {Роз. }}$ - кількість розвіданих зразків ОВТ, од.

Ймовірність виконання ремонту зразку ОВТ після виникнення бойового пошкодження - це ймовірність того, що зразок буде відновлена після відмови за даний час і за певних умов ремонту: 


$$
P_{B}(\tau)=P\left\{t_{B} \leq \tau\right\}
$$

де $t_{B}$ - випадковий час відновлення зразку, год.;

$\tau$ - заданий час відновлення, год.

Ймовірність $P_{B}(\tau)$ становить за своїм математичним змістом функцію розподілу або інтегральний закон розподілу часу відновлення:

$$
P_{B}(\tau)=\int_{0}^{\tau} f\left(t_{B}\right) d t_{B},
$$

де $f\left(t_{B}\right)$ - щільність розподілу часу відновлення.

$$
\text { Якщо } \begin{aligned}
f\left(t_{B}\right)= & \mu \cdot e^{-\mu t_{B}}, \text { то } \\
& P_{B}(\tau)=1-e^{-\mu \tau},
\end{aligned}
$$

де $\mu$ - інтенсивність відновлення відмов машини, що становить кількість відновлень, виконаних за одиницю часу, 1/год.

Таким чином, за допомогою залежностей (112) можна визначити узагальнений коефіцієнт від- новлюваності зразків ОВТ $K_{ж}$ та прогнозувати відновлюваність зразків на період проведення бою.

\section{Висновки}

1. Отримано комплексний показник, який дозволяє оцінити рівень відновлюваності зразків ОВТ, як складової боєздатності ОВТ.

2. Визначення сутності та змісту категорії “відновлюваність зразків ОВТ”, ii місця і ролі серед інших категорій теорії технічного забезпечення, вироблення єдиного розуміння цього питання, що відповідають інтересам як подальшого розвитку військової науки, так і вирішення практичних завдань, що стоять перед військами. Вивчення проблеми відновлюваності зразків ОВТ дозволяє створити математичний апарат іiі оцінки і прогнозування.

\section{Список літератури}

1. Чабаненко П.П. Закономірності та особливості оцінювання ефективності систем у бойових діях за ймовірнісними моделями / П.П. Чабаненко // Наука і оборона. - 2016. - № 4. - С. 16-22.

2. Оцінка ефективності використання броньованих автомобілів для проведення технічної розвідки / А.В. Ковтун, С.А. Кудімов, В.М. Савченко, П.О. Степанов // Честь і закон. - 2020. - № 2(73). - С. 33-41.

3. Проблеми технічного оснащення Збройних Сил України та шляхи їх розв'язання в сучасних умовах / І.Б. Чепков І.В. Борохвостов, В.К. Борохвостов, А.О. Русевич // Наука і оборона. - 2014. - № 3. - С. 43-50.

4. Ахметов Р.Р. Основы материально-технического обеспечения войск / Р.Р. Ахметов. - Омск: СибАДИ, 2011. $152 \mathrm{c}$.

5. Павловський О.В. Метод прогнозування обсягів завдань, що покладатимуться на ремонтно відновлювальні органи під час операції (бойових дій) / О.В. Павловський // Збірник наукових праць Харківського університету Повітряних Сил. - 2016. - № 2. - С. 15-18.

6. Дачковський В.О. Методика оцінювання відновлюваності озброєння та військової техніки / В.О. Дачковський, Л.М. Родченко // Сучасні інформаційні технології у сфері безпеки та оборони. - 2019. - № 3(36). - С. 89-96.

7. Мацько О.Й. Основи організації експлуатації і ремонту озброєння військової техніки / О.Й. Мацько - К.: НУОУ, 2018. $-400 \mathrm{c}$.

8. Відновлюваність як одна з найважливіших техніко-експлуатаційних властивостей машин військового призначення / М.О. Шишанов, Л.І. Кобяков, М.М. Шевцов, С.С. Котляревський // Соціальний розвиток і безпека. - 2017. № 1(1). - C. 3-13.

9. Куцопало В.С. Основы сохранения и восстановления боеспособности вооружения / В.С. Куцопало. - М.: МО, 1976. $-351 \mathrm{c}$.

10. ГОСТ В3-5977-85. Машины гусеничные военные. Ремонтопригодность и восстанавливаемость номенклатура показателей, методы оценки при проектировании и испытаниях.

11. Дедков В.К. Основные вопросы эксплуатации сложных систем / В.К. Дедков, Н.А. Северцев. - М.: Высшая школа, 1976. - 405 с.

12. Стандарт США MJL-STD-721B.

13. Ковтун А.В. Основи надійності автомобільної техніки / А.В. Ковтун. - Х.: АВВ, 2013. -145 с.

14. Вентцель Е.С. Теория вероятностей / Е.С. Вентцель, Л.А. Овчаров. - М.: Наука, 1973. - 368 с.

Надійшла до редколегії 03.08.2020

Схвалена до друку 15.09.2020 
Відомості про авторів:

Табуненко Володимир Олександрович

кандидат технічних наук доцент

професор

Харківського національного університету Повітряних

Сил ім. І. Кожедуба,

Харків, Україна

https://orcid.org/0000-0003-1347-5390

\section{Марценяк Олександр Петрович}

старший викладач кафедри

Національної академії

Національної гвардії України,

Харків, Україна

https://orcid.org/0000-0002-1215-8986

\section{Кужелович Віктор Іванович}

старший викладач

Національної академії

Національної гвардії України,

Харків, Україна

https://orcid.org/0000-0001-5361-8400
Information about the authors:

Volodymyr Tabunenko

Candidate of Technical Sciences Associate Professor

Professor

of Ivan Kozhedub Kharkiv National

Air Force University,

Kharkiv, Ukraine

https://orcid.org/0000-0003-1347-5390

\author{
Alexsander Martseniak \\ Senior Instructor \\ of National Academy \\ of the National Guard of Ukraine, \\ Kharkiv, Ukraine, \\ https://orcid.org/0000-0002-1215-8986
}

\author{
Viktor Kuzhelovych \\ Senior Instructor \\ of National Academy \\ of the National Guard of Ukraine, \\ Kharkiv, Ukraine, \\ https://orcid.org/0000-0001-5361-8400
}

\section{СОВЕРШЕНСТВОВАНИЕ МЕТОДОВ ОЦЕНКИ ПОКАЗАТЕЛЕЙ ВОССТАНАВЛИВАЕМОСТИ ВООРУЖЕНИЯ И ВОЕННОЙ ТЕХНИКИ В УСЛОВИЯХ БОЕВЫХ ДЕЙСТВИЙ}

В.А. Табуненко, А.П. Марценяк, В.И. Кужелович

В настоящее время обеспечение боеспособности вооружения и военной техники на необходимом уровне зависит от организации мероприятий технического обеспечения, его обновления, которое осуществляется с ичелью приведения поврежденных изделий военной техники в готовность к боевому применению. Но, понятие восстанавливаемости вооружения и военной техники не определено государственным стандартам, вследствие чего возникают всевозможные толкования этого свойства. В работе проведен анализ наиболее употребляемых определений восстанавливаемости и полученные зависимости для оченки уровня восстанавливаемости изделий военной техники при выполнении задач по назначению.

Ключевые слова: система восстановления, вооружение и военная техника, система технического обеспечения, комплексные свойства, коэффициент восстанавливаемости.

\section{IMPROVEMENT OF METHODS FOR ASSESSING THE RESTORABILITY OF WEAPONS AND MILITARY EQUIPMENT IN THE CONDITIONS OF BATTLE OPERATIONS}

V. Tabunenko, A. Martsenyak, V. Kuzhelovich

At present, ensuring the combat effectiveness of weapons and military equipment at the required level depends on the organization of technical support measures, its renewal, which is carried out with the aim of bringing damaged items of military equipment in readiness for combat use. But, the concept of recoverability of weapons and military equipment is not defined by state standards, as a result of which there are all kinds of interpretations of this property. The paper analyzes the most commonly used definitions of recoverability and the resulting dependencies for assessing the level of recoverability of military equipment when performing tasks as intended. The scientific basis for research to assess the level of reproducibility of armaments and military equipment is the theory of efficiency of armaments and military equipment, operation of armaments and military equipment, the basics of the theory of reliability of armaments and military equipment, probability theory and mathematical statistics. Thus, with the help of the proposed dependences it is possible to determine the generalized coefficient of reproducibility of samples of military equipment and predict their reproducibility for the period of combat. The paper provides a comprehensive indicator that allows to assess the level of reproducibility of samples of military equipment as a component of their combat capability. Defining the essence and content of the category "reproducibility of weapons and military equipment", its place and role among other categories of technical support theory, developing a common understanding of this issue, in the interests of further development of military science and solving practical problems facing troops. The study of the problem of reproducibility of samples of armaments and military equipment allows to create a mathematical apparatus for its evaluation and forecasting.

Keywords: recovery system, weapons and military equipment, technical support system, complex properties, coefficient of recovery. 